\title{
Effect of Laboratory Produced Pawpaw (Carica Papaya) and Pineapple (Ananas Comonsus (L.) Merr, syn) Wines on Enzyme Activities of Rat Liver
}

\author{
Awe, S*, Madueke, S.N \\ Department of Biosciences, Salem University, Lokoja, Kogi State Nigeria
}

\begin{abstract}
The toxicological effect of laboratory prepared fruit wines (Pawpaw wine and Pineapple wine) at different alcoholic content on enzyme activities of albino rat (Wistar strain) was investigated. Sixty rats were divided into four groups: group I (negative control) received no wine, group II subdivided into three subgroup A, B and C received $6.25 \mathrm{ml} / \mathrm{mg}$ body weight of 5, 7.5 and $10 \%$ alcohol content of Red wine (positive control) respectively, group III subdivided into three subgroup A, B and C received $6.25 \mathrm{ml} / \mathrm{mg}$ body weight of 5, 7.5 and $10 \%$ alcohol content of Pawpaw wine respectively, while, group IV subdivided into three subgroup A, B and C received $6.25 \mathrm{ml} / \mathrm{mg}$ body weight of $5,7.5$ and $10 \%$ alcohol content of Pineapple wine respectively for eighteen days. Enzyme activities indicated that both red wine and the fruit wines (Pawpaw wine and Pineapple wine) at 7.5 and $10 \%$ alcohol induced marked liver failure characterized by a significant increase ( $<<$ 0.05) in serum aspartate trnsaminase (AST, EC 2.6.1.1), alanine transaminase (ALT, EC 2.6.1.2), Lactate dehydrogenase (LDH ,EC 1.1.1.27) and Gamma glutamyl transpeptidase (GGT , EC 2.3.22) activities . In conclusion, $5 \%$ alcohol content of the Pawpaw wine and Pineapple wine showed no apparent disruptions of the normal liver structure by enzyme activities assessment.
\end{abstract}

Keywords Pawpaw, Pineapple, Toxicology, Enzyme activities, Wine

\section{Introduction}

Wine is an alcoholic beverage, made of fermented fruit juice, usually from grapes. The natural chemical balance of grapes lets them ferment without the addition of sugars, acid, enzymes, or nutrients[1]. Apples, berries and blackcurrants are sometime also fermented for wine production. Non-grape wines are called fruit wine or country wine[2]. Examples are: "apple wine" or "elderberry wine". Wines are categorized using a number of different methods. Sometimes they are grouped into different categories by grape variety, region of origin, by colour, by name of the wine maker or viticulturalist, or by production technique. Three basic groups of wines are most easily distinguishable for the consumer: table wines, sparkling wines and fortified wines[3].

Studies have shown that alcohol may benefit many bodily organs, including the heart and the brain. However, the benefits are available only when wine is taken in moderation as over consumption of alcohol including wine can cause some diseases including cirrhosis of the liver and alcoholism[4]. Pineapple (Ananas comonsus(L.) Merr, Syn)is a fruit

* Corresponding author:

asflor5@yahoo.com (Awe, S)

Published online at http://journal.sapub.org/microbiology

Copyright (C) 2011 Scientific \& Academic Publishing. All Rights Reserved bearing plant of the family Bromeliaceae native to tropical and sub-tropical. It has 30 to 40 stiff succulent leaves closely spaced in a rosette on a thick, fleshy stem. With commercial varieties, a determinate inflorescence forms about 15 to 20 months after planting in a flower stock 100 to $150 \mathrm{~mm}$ (4 to 6 inches) in length. The original separate lavender flowers together with their bracts, each attached to a central axis core, become fleshy and fuse to form the pineapple fruit which ripens in five to six months, after flowering begins[5].

The fruit contains vitamin $\mathrm{C}$, iron and other minerals. It acts as an effective laxative. Juice of the ripe fruit cures gastric irritability in fever and is very helpful in jaundice. It contains a proteolytic enzyme bromelain, which digests food by breaking down protein. Pineapple is a good source of manganese, as well as containing significant amounts of Vitamin C and Vitamin B1. Pineapples are rich in manganese, a trace mineral that is needed for body to build bone and connective tissues[6].

Pawpaw (Carica papaya) belongs to the family Caricaceae, a native of tropical America, but now spread all over the tropical regions of the world. It is know by different names in different countries, such as Mamao (Brazil), Cechoso (Venezuela), Frutabomba (Cuba), papaya in Malaysia and Thailand[7, 8 ]. Pawpaw is grown mostly for fresh consumption or for production of latex. Pawpaw fruit is a good source of carbohydrate, vitamins ( $\mathrm{Vc}$ and $\mathrm{Va}$ ) and 
minerals (copper and magnesium)[9]. The skin is smooth and thin, shady from deep orange or yellow when ripe to green. The flesh varies from 2.5 to $5.0 \mathrm{~cm}$ in thickness, it is a very wholesome fruit and relished for the attractive colour, flavour, succulence and characteristic aroma[10]. Fresh pawpaw fruits are very perishable, thereby making their export problematic. Large quantities of these fruits are produced yearly in Nigeria in amount that are in excess of their consumption and are disposed off due to non- availability of or poor storage facilities. The nutrients that are so lost can be harnessed and made available all year round, if the fruits are put to other use such as wine production.

This study is an investigation of the toxicological effect of laboratory produced wines from Pawpaw and Pineapple compared with red wine.

\section{Materials and Methods}

\subsection{Wine Samples}

Pawpaw and Pineapple wine were produced in the laboratory of the Department of Microbiology University of Ilorin, Ilorin, Nigeria using Saccharomyces cerevisae purchased from E. C Kraus USA as a fermenting organism[3]. Red wine (Carlo Rossi) imported from USA was used as a control for this work.

The experiments were performed during 2009 to 2010 in the Microbiology laboratories of University of Ilorin and Ajayi Crowther University, Oyo Nigeria.

Ten Kilogram $(10 \mathrm{~kg})$ of ripe, fresh and healthy peeled pawpaw and pineapple fruits was, blended with sterilized blender to give the fruit pulp and mixed with warm water $\left(45^{\circ} \mathrm{c}\right)$ in the ratio $(1: 2)$ to give the 'must' needed for wine production. The must was sterilized with sodium metabisulphate solution to remove microbial contaminants. Standardized campdentablet, $30 \%$ sucrose and yeast nutrient were added to the must and allowed to stay for 24 hours, after which yeast was added[11].

\subsection{Fermentation Process}

Standardized amount of yeast was added to must in a fermenting jar by sprinkling it over the surface of the juice. The inoculated must was covered with muslin cloth and incubated at room temperature $\left(29 \pm 2^{0} \mathrm{C}\right)$. The fermenting must was aerated daily by stirring twice to encourage yeast multiplication[11]. Aerobic fermentation was terminated after 6 days and the must was sieved to remove the shaft and debris of the crushed fruits.

The filtrate obtained after sieving the must was transferred into anaerobic fermentation jar and incubated at room temperature. An air trap was fixed to the fermenting jar to indicate the end of fermentation. Campdentablet was added to the filtrate to supply sulfur dioxide gas. Fermentation was terminated after six weeks. The produced wine was then stored at room temperature to allow the yeast to flocculate. The wine was racked monthly for three months to clear the wine and then aged. After aging for 6 months, the wine was filtered using pressurized filtering kit, decanted into sterile bottles and corked.

\subsection{Animals and Treatments}

Animals weighing an average of $160 \mathrm{~g}$ were bred and housed in the Animal House of the Department of Chemical science, Ajayi Crowther University, Oyo, Nigeria. They were kept in wire meshed cages and fed with commercial rat chow (Bendel feeds Nigeria ltd) and supply water $a d$ libitum.

Sixty (60) albino rats (wistar strain) were divided into four groups:

group I consist of only 6 rats served as the negative control to which only distilled water (no wine) was administered orally.

group II consist of 18 rats divided into 3 subgroups A, $\mathrm{B}, \mathrm{C}$ received $6.25 \mathrm{ml} / \mathrm{kg}$ body weight of $5 \%, 7.5 \%$ and $10 \%$ alcohol content of the Red wine (positive control) respectively for eighteen days.

group III consist of 18 rats divided into 3 sub groups A, $\mathrm{B}, \mathrm{C}$ received $6.25 \mathrm{ml} / \mathrm{kg}$ body weight of $5 \%, 7.5 \%$ and $10 \%$ alcohol content of the Pawpaw wine respectively for eighteen days.

group IV consist of 18 rats divided into 3 sub groups A, $\mathrm{B}, \mathrm{C}$ received $6.25 \mathrm{ml} / \mathrm{kg}$ body weight of $5 \%, 7.5 \%$ and $10 \%$ alcohol content of the Pineapple wine respectively for eighteen days.

\subsection{Determination of Liver and Serum AST and ALT Activities}

Liver and Serum AST and ALT activities were determined using Randox diagnostic kits. Determination of AST and ALT activities were based on the principle described by[12].

\subsection{Determination of Liver and Serum LDH Activities}

Liver and Serum LDH activities were determined using Randox diagnostic kits following the principle described by [12].

\subsection{Determination of Liver and Serum GGT Activities}

Liver and Serum GGT activities were determined using Randox diagnostic kits following the principle described by[13].

\subsection{Statistical Analysis}

The data were analyzed using one way ANOVA followed by Duncan multivariable post-hoc test for comparison between control and treated rats in all groups. P values less than 0.05 were considered statistically significant.

\section{Results}

Figure 1A showed the effect of different wines of varying alcoholic contents on liver AST activities, while figure 1B 
shows the effect of repeated, oral administration of wines of different alcoholic contents on serum AST. While the effect of different wines of varying alcoholic contents on liver ALT activities was presented in Figure 2A .Figure 2B Shows the effect of repeated, oral administration of wines of different alcoholic contents on serum ALT. Figure 3A and 3B showed the effect of different wines of varying alcoholic contents on liver and serum LDH activities respectively. Effect of repeated oral administration of wines of different alcoholic contents on liver and serum GGT activities respectively was presented in figure $4 \mathrm{~A}$ and $4 \mathrm{~B}$. All the results showed that there were a significant increased $(p<0.05)$ in the level of all the four enzymes activities in those rats treated with wines of 7.5 and $10 \%$ alcoholic content when compared with the control. However, at 5\% alcoholic content the wine show no significant effect on the enzymes activities when compared with the control.

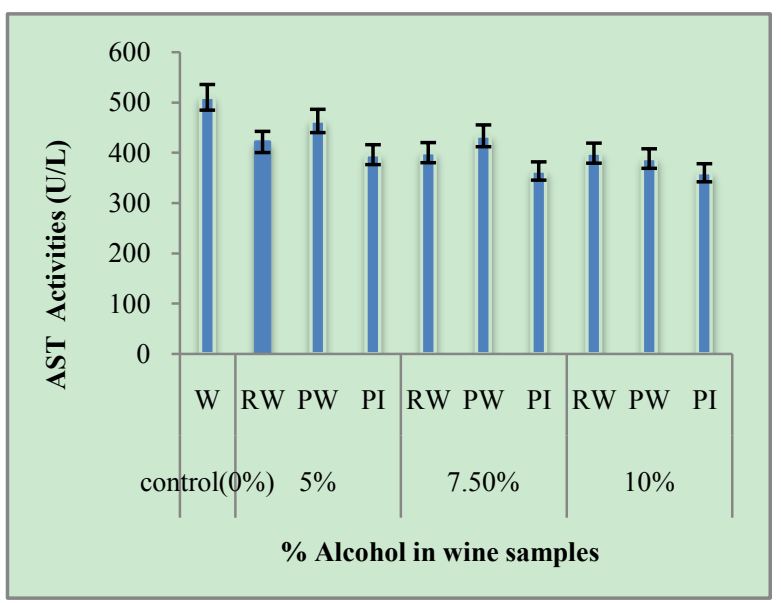

Key: $\mathrm{W}=$ Water; $\mathrm{RW}=$ Red Wine; $\mathrm{PW}=$ Pawpaw Wine; $\mathrm{PI}=$ Pineapple Wine The values are the Means \pm SD (range) for six rats in each group.

* Significantly different from the control, $\mathrm{p}<0.05$ (Duncan's multiple comparison test).

Figure 1A. Effect of Different wines of varying alcoholic contents on liver AST activities

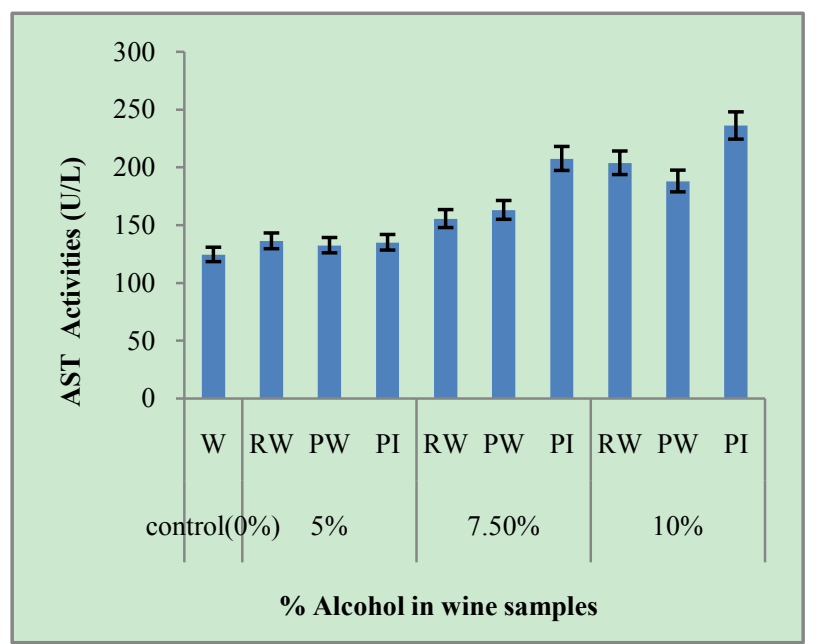

Key: $\mathrm{W}=$ Water; RW = Red Wine; PW = Pawpaw Wine; PI = Pineapple Wine The values are the Means \pm SD (range) for six rats in each group.

* Significantly different from the control, $\mathrm{p}<0.05$ (Duncan's multiple comparison test)

Figure 1B. Effect of Different wines of varying alcoholic contents on serum AST activities

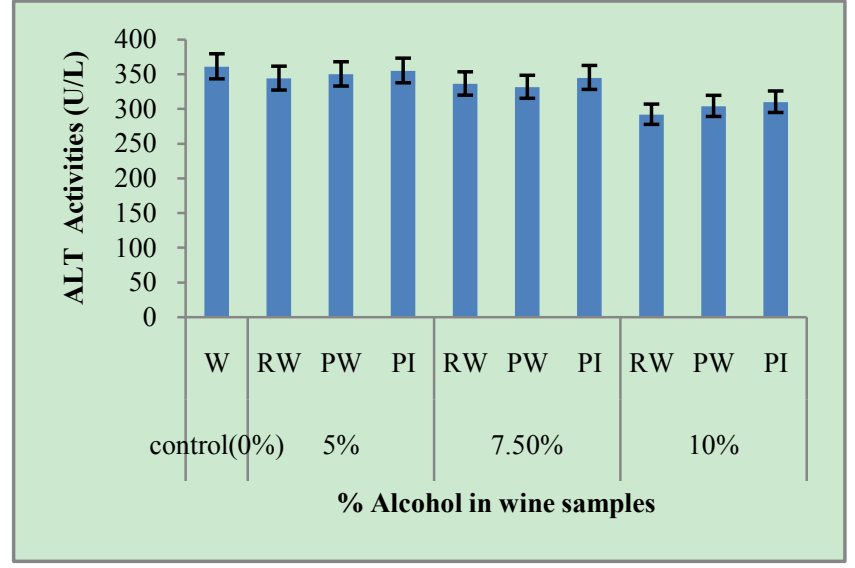

Key: $\mathrm{W}=$ Water; $\mathrm{RW}=$ Red Wine; $\mathrm{PW}=$ Pawpaw Wine; $\mathrm{PI}=$ Pineapple Wine The values are the Means $\pm \mathrm{SD}$ (range) for six rats in each group.

* Significantly different from the control, $\mathrm{p}<0.05$ (Duncan's multiple comparison test)

Figure 2A. Effect of Different wines of varying alcoholic contents on liver ALT activities

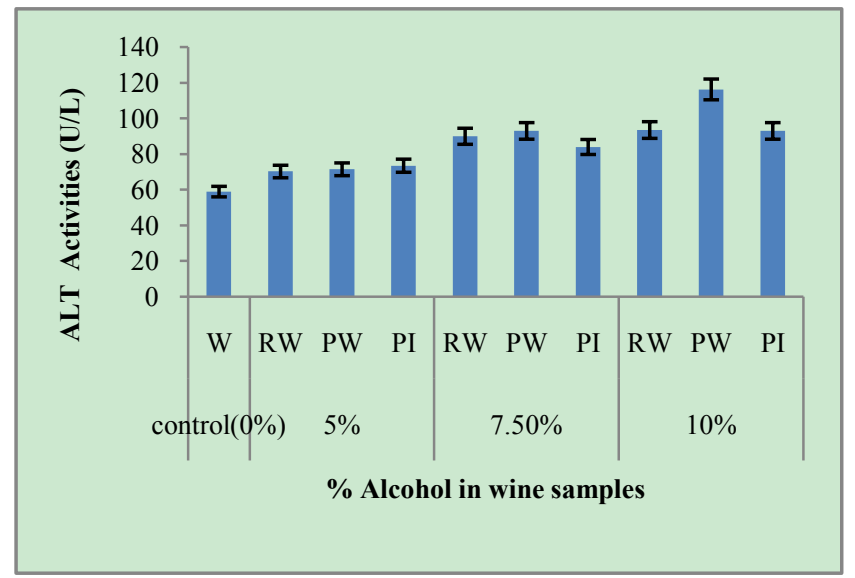

Key: $\mathrm{W}=$ Water; RW = Red Wine; PW = Pawpaw Wine; PI = Pineapple Wine The values are the Means \pm SD (range) for six rats in each group.

$*$ Significantly different from the control, $\mathrm{p}<0.05$ (Duncan's multiple comparison test).

Figure 2B. Effect of Different wines of varying alcoholic contents on serum ALT activities

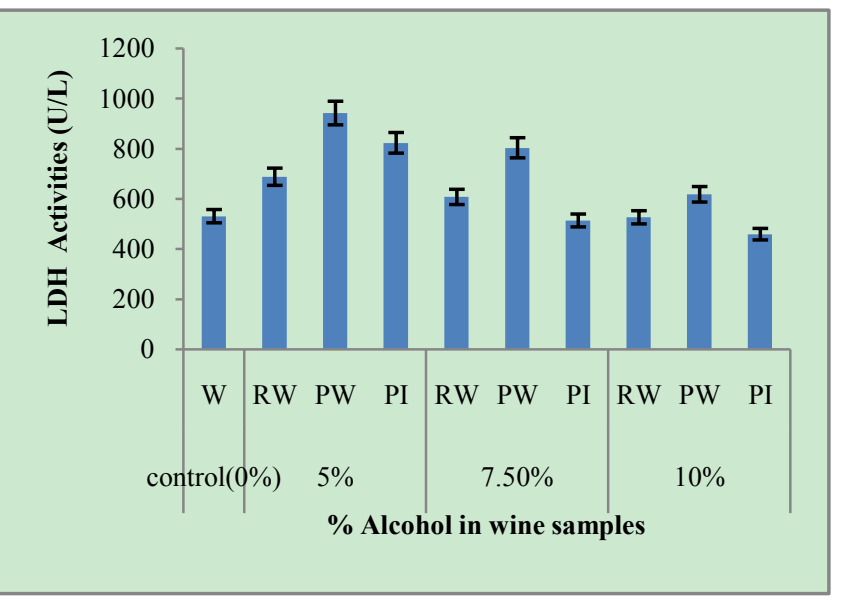

Key: $\mathrm{W}=$ Water; RW $=$ Red Wine; $\mathrm{PW}=$ Pawpaw Wine; $\mathrm{PI}=$ Pineapple Wine The values are the Means $\pm \mathrm{SD}$ (range) for six rats in each group.

* Significantly different from the control, $\mathrm{p}<0.05$ (Duncan's multiple comparison test).

Figure 3A. Effect of Different wines of varying alcoholic contents on liver LDH activities 


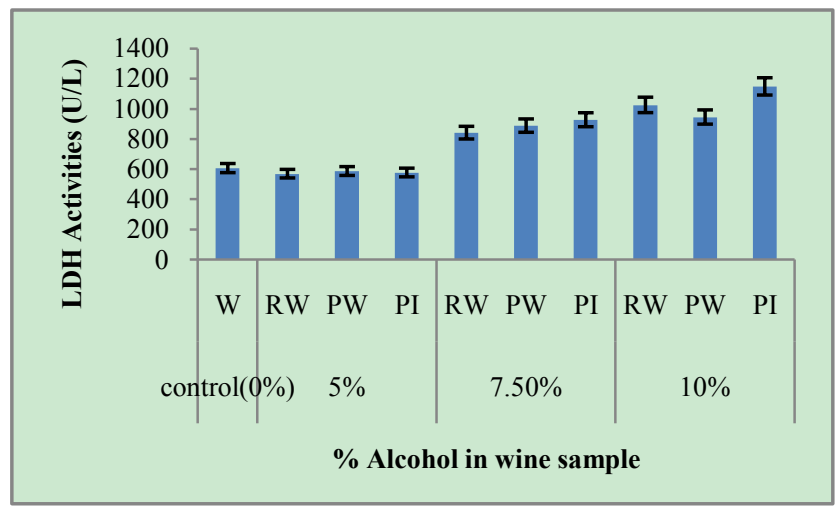

Key: $\mathrm{W}=$ Water; $\mathrm{RW}=$ Red Wine; $\mathrm{PW}=$ Pawpaw Wine; $\mathrm{PI}=$ Pineapple Wine The values are the Means \pm SD (range) for six rats in each group.

* Significantly different from the control, $\mathrm{p}<0.05$ (Duncan's multiple comparison test).

Figure 3B. Effect of Different wines of varying alcoholic contents on serum LDH activities

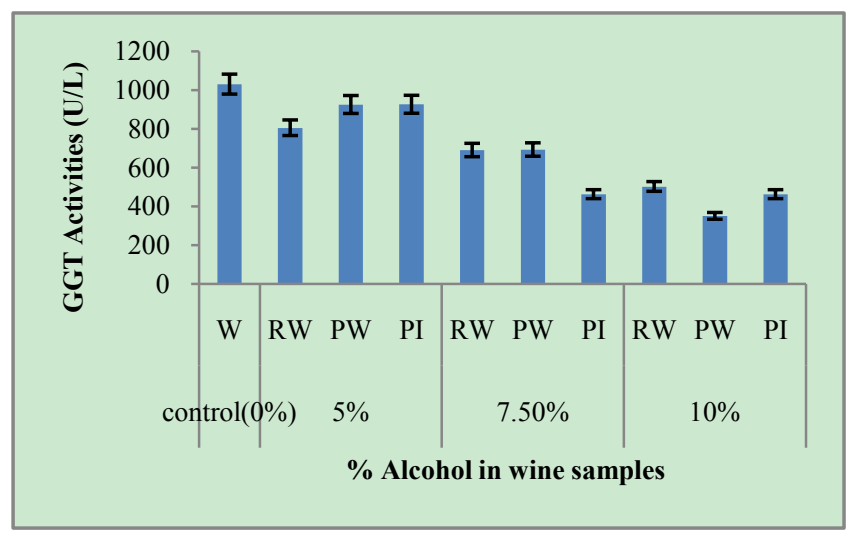

Key: $\mathrm{W}=$ Water; $\mathrm{RW}=$ Red Wine $\mathrm{PW}=$ Pawpaw Wine; $\mathrm{PI}=$ Pineapple Wine The values are the Means \pm SD (range) for six rats in each group.

* Significantly different from the control, $\mathrm{p}<0.05$ (Duncan's multiple comparison test).

Figure 4A. Effect of Different wines of varying alcoholic contents on liver GGT activities

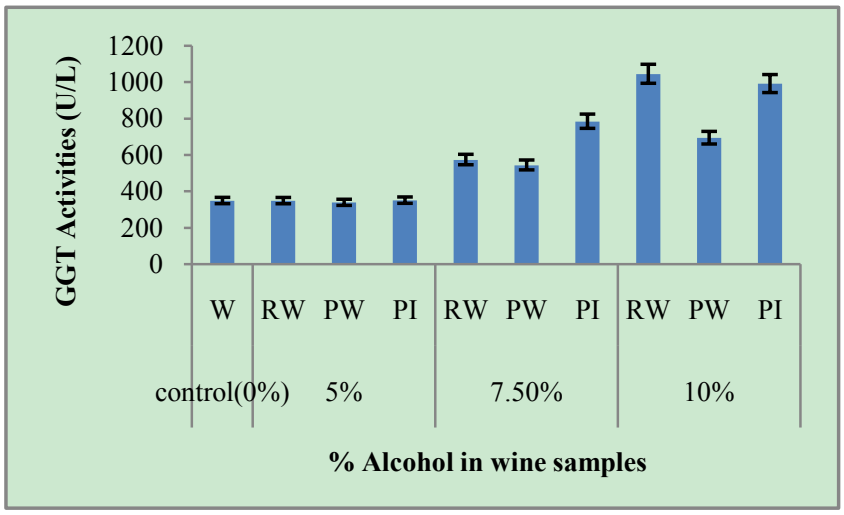

Key: $\mathrm{W}=$ Water; RW = Red Wine; $\mathrm{PW}=$ Pawpaw Wine; $\mathrm{PI}=$ Pineapple Wine The values are the Means \pm SD (range) for six rats in each group.

* Significantly different from the control, $\mathrm{p}<0.05$ (Duncan's multiple comparison test).

* Significantly different from the control, $\mathrm{p}<0.05$ (Duncan's multiple comparison test).

Figure 4B. Effect of Different wines of varying alcoholic contents on serum GGT activities
Alcohol is one of the factors most frequently associated with increased liver enzyme and the association between alcohol intake and alcohol-induced liver disease is well known. The Italian Dionysos study showed that alcohol was suspected to be the cause in $23 \%$ of all cases of liver disease, with a dose-dependent increase in the risk of developing liver disease[14, 15].

The measurement of the activities of various enzymes in the tissues and body fluids play a significant role in disease investigation and diagnosis and detection of tissue cellular damage[16]. Tissues enzyme assay reveals tissue damages even before structural damages are detected by conventional histological techniques[17]. The marker enzymes assayed are specifically located in some cell; however, they can leak into the serum or other parts as a result of injury to the cell where they are located $[18,19]$.

The values of AST and ALT activities in the liver and serum respectively (Figures 1, 2, 5 and 6) showed that administration of the red wine and fruit wines had effect on the liver when compared to the control. Low levels of AST is normally found in the blood, however, when the liver or heart is damaged additional AST is released into the bloodstream. It rises within 6 to 10 hours and remains high for 4 days[18]. ALT is produced within the cells of the liver and is the most sensitive marker for liver cell damage[19-21]. Any form of hepatic cell damage can result in an elevation in the ALT; as the cells are damaged, the ALT leaks into the bloodstream leading to a rise in the serum levels. Therefore, the high AST and ALT levels in the serum of rats to which the wines (red wine and fruits wine produced) were administered are indications of leakage into the bloodstream due to liver damage[22]. Although ALT is present in several organs and in muscle, the highest levels are in the liver, which makes this enzyme a more specific indicator of liver injury. Both AST and ALT are released into the blood in greater amounts when hepatocytes are damaged.

GGT is a membrane enzyme and the most sensitive marker of hepatobiliary disease. However, its routine clinical use is not recommended, as it cannot by itself indicate a specific cause of liver disease, although measuring the GGT level can help determine a hepatic origin for an isolated elevation of alkaline phosphatase[23].

Lactate dehydrogenase (LDH) is an enzyme found in the cells of many body tissues, including the heart and liver[20]. Owing to its widespread distribution in the tissues, elevation of the total LDH in the serum is generally of little value in diagnosis. High values commonly occur after myocardiac infarction, in megaloblastic anemia, progressive muscular dystrophies and in neoplastic diseases especially widely disseminated forms[4].

The result of the enzyme activities clearly demonstrated that the effect of the wines was dose dependent.

\section{Conclusions}

This study has shown that the locally available fruits can

\section{Discussion}


be used to produce wines that are comparable to imported. In view of the toxicological effect of alcohol, it is recommended that if wine must be consumed, it should be at a maximum of alcohol content of $5 \%$ to minimize liver damage.

\section{ACKNOWLEDGEMENTS}

I wish to express my gratitude to Dr. K.I.T Eniola, Mrs. Awe, O.A, Favour and Opeyemi Awe for their contributions toward this study.

\section{REFERENCES}

[1] Johnson, H., 2003, Hugh Johnson's wine companion $5^{\text {th }}$ edition, Mitchell Beazley "The Encyclopedia of Wines. Vineyards and Winemakers"

[2] Batmanighiji, N., 2006, From persia to nepa:wine at the persian table. Washington, DC: Maye Publisher ISBN 1-9338 23-00-3.

[3] Bisson, L. F. and Butzkc, C. E, 2007. History of wine making. In WINE, Microsoft R Encarta.(Access on: March 11/5/ 2010)

[4] Awe, S and E.Tunde Olayinka., 2011, Effect of cashew wine on histology and enzyme activities of rat liver. Journal of Toxicology and Environmental Health Sciences 3 (2) 31- 38.

[5] Coppens d'Eeckenbrugge, Geo; Freddy Leal., 2003, "Chapter 2: Morphology, anatomy, and taxonomy". In D.P Bartholomew,

[6] McKenzie, G., 2010, "A little bit of history". Journal of the Bromeliad Society 60 (4): 187-189.

[7] Morton, J., 2006, Papaya: Carica papaya L. http:// www. hotrpuredue.edu/newcrop/morton/papaya ars.html. Retrieved $(5 / 6 / 2010)$.

[8] Papaya., 2008, In Wikipedia, The free Encyclopedia. http://en.wikipedia.org/w/index.php?title= pa paya\&o/did=22 $9449294(05 / 06 / 2010)$

[9] Wall, M.M., 2006, Ascobic acid, vitamin A , and mineral composition of banana (Musa sp.) and papaya (Carica papaya) Cultivars grown in Hawaii. Journal of Food Composition and Analysis 19 (5) 434-445.
[10] Desai, U. T. and Wagh, A. N., 1995, Handbook of science and technology: production, composition, storage and processing. Marcel Dekker, Inc. 207 madison Avenue, New York. New York 10016 Pp. 297-311.

[11] Berry, C. J. J., 2000, First steps in wine making. Published by G. W. Kent, Inc. 3667 Morgan Road, Ann Arbor M I 48108. pp 235 ..

[12] Reitman, S; and Frankel, S.,1957, Determination of plasma amino transferases activities. American Journal of Clinical Pathology.28:56.

[13] Szasz, G .,1976, Reaction rate method for gama- glutamyl transeptidase activities in urinary excretion with corresponding tissue pattern in rats. Pharmacal Toxication

[14] Bellentani S, Tiribelli C, and Saccoccio G., 1994, Prevalence of chronic liver disease in the general population of Northern Italy:the Dionysos study. Hepatology; 20:1442-49.

[15] Bellentani S, Saccoccio G, and Costa G., 1997, Drinking habits as cofactors of risk for alcoho induced liver damage. Gut; 41:845-50.

[16] Malomo, S.O ., 2000, Toxicological implication of ceftriaxome administration in rats. Nig. J Biochan Mol. Bial. 15(1):33-35.

[17] Akanji, M.A and Ngaha, E.O(1989).Effect of repeated administration of beremil on urinary excretion with corresponding tissue pattern in rats. Pharmacal Toxication 64:272-275.

[18] Healthwise .,2008, .http:www.webmd.com/digestives-disord ers/aspartate-aminotransferase-ast. Accessed 25 April,2009

[19] Jensen, J.E and Freese, D., 2009, Liver function tests. colorado center for digestive disorders 205s. Suite A Longmont Co. 80501 .

[20] Janis, O. F., 2006, Gale encyclopedia of medicine. Published by the Gale Groups.

[21] Nelson, David. L and Cox, Michael, M., 2003, Lehninger principles of biochemistry 3rd edition, worth publishers. Inc. New York Pp541-455, 626,845.

[22] Jacobs, M.B., 1999, The chemistry analysis of food and food product. 3rd Edition CBS publishers and Distributors, New Delhi India.

[23] Margarian GJ, Lucas LM, and Kumar K L., 1992, Clinical significance in alcoholic patients of commonly encountered laboratory test results. West J Med. 156:287-294. 